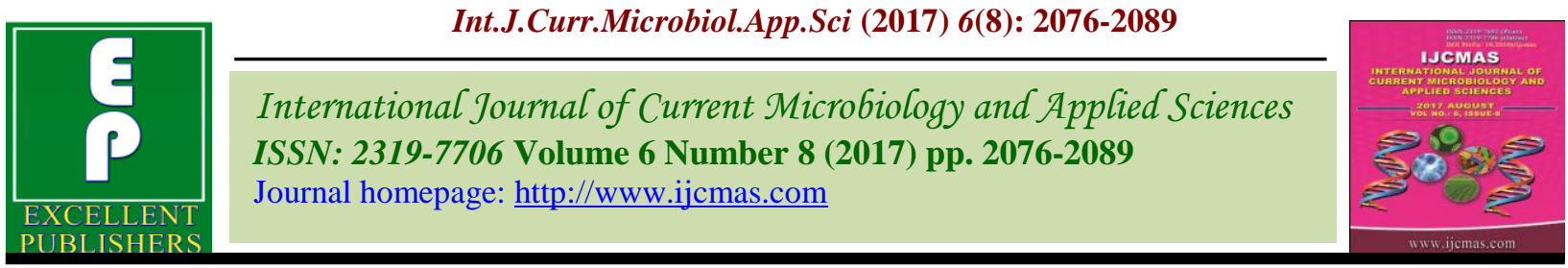

Original Research Article

https://doi.org/10.20546/ijcmas.2017.608.247

\title{
Effect of Different Growing Media on Growth and Flower Production of LA Hybrid Lily
}

\author{
Smita Rajera*, Puja Sharma and Bharti Kashyap Priyanka Sharma
}

Department of Floriculture and Landscape Architecture, College of Horticulture, Dr. Yashwant Singh Parmar University of Horticulture and Forestry, Solan (Nauni), HP - 173 230, India

*Corresponding author

\section{A B S T R A C T}

\section{Keywords \\ Sand, Soil, FYM, Cocopeat, Vermicompost etc. \\ Article Info \\ Accepted: \\ 19 June 2017 \\ Available Online: \\ 10 August 2017}

The present investigation entitled, 'Effect of growing media on growth, flower production of LA hybrid lilies' was carried out at the experimental farm of Department of Floriculture and Landscape Architecture, Dr. Y.S. Parmar University of Horticulture and Forestry, Nauni, Solan (H.P) during 2014-2015. The experiment was laid out in a Completely Randomized Design (factorial) consisting of two cultivars i.e. 'Batistero' and 'Courier' and seven growing media $\mathrm{M}_{1}$-sand+soil+FYM, (1:1:1, v/v), $\mathrm{M}_{2}$-sand+soil+FYM $(2: 1: 1 ; \mathrm{v} / \mathrm{v}), \quad \mathrm{M}_{3}$-cocopeat+FYM $\quad(1: 1 ; \mathrm{v} / \mathrm{v}), \quad \mathbf{M}_{4}$-cocopeat+soil+FYM $\quad(1: 1: 1 ; \mathrm{v} / \mathrm{v}), \quad \mathbf{M}_{5^{-}}$ $\mathbf{M}_{1}+$ cocopeat $(1: 1 ; \mathrm{v} / \mathrm{v}), \mathbf{M}_{6}-\mathrm{M}_{1}+$ vermicompost $(2: 1 ; \mathrm{v} / \mathrm{v})$ and $\mathbf{M}_{7}-\mathbf{M}_{1}+$ vermicompost + cocopeat $(2: 1: 1 ; \mathrm{v} / \mathrm{v})$. Findings revealed that earliest sprouting, number of leaves per plant, days taken for flowering, number of flowers/spike, duration of flowering, weight of stem and vase life was recorded best when LA hybrids bulbs were grown in $\mathbf{M}_{7}: \mathrm{M}_{1}+$ vermicompost + cocopeat $(2: 1: 1, \mathrm{v} / \mathrm{v})$. However, plant height, stem length, bud length, size of flower, was recorded best when LA hybrids bulbs were grown in $\mathrm{M}_{1}$ - sand+soil+FYM, $(1: 1: 1, v / v)$. Hence, it can be concluded that for quality flower production of LA hybrids cultivars a medium containing (sand+soil+FYM) + vermicompost + cocopeat $(2: 1: 1, \mathrm{v} / \mathrm{v})$ was found most suitable.

\section{Introduction}

Lilium is one of the most beautiful and popular ornamental bulbous flowers. The genus Lilium belongs to family Liliaceae and comprises of about 100 species. They have been admired long for their aesthetic quality and have often been depicted as a symbol of purity and regality Lilies are native to Northern hemisphere in Asia, Europe and North America. Lilies have been found to grow from sea level to an altitude up to 2000 metres, covering alkaline, acidic and other types of soils. As far as their distribution is concerned, about 50-60 species are reported in Asia, 24 in North America and 12 in Europe (Dole and Wilkins, 1999). Lilies are wonderful ornamental plants used as commercial cut flower owing to their magnificent colours. These are also used as a border plant, pot plant and in landscaping. Lilies are known to be grown on a variety of soils. For quality cut flower production, however a good growing medium should be used. Lilies have non-tunicated tender bulbs and require porous, airy well drained growing medium with good quality of humus or organic matter. Characteristics of different 
materials used as substrates have the direct and indirect effects on plant growth and crop production. The characteristics of ideal growing medium for its successful cultivation are porous with better aeration, well drained, good water holding capacity and cheap too. Therefore, standardization of a suitable growing medium for its cultivation is of utmost importance.

\section{Materials and Methods}

The experimental farm is located at an altitude of $1270 \mathrm{~m}$ above mean sea level at a latitude of $32^{\circ} 52^{\prime} \mathrm{N}$ and longitude of $77^{\circ} 11^{\prime}$ $30^{\prime \prime}$ E. Climate of Nauni, in general, is subtemperate to sub-tropical and characterized by mild summer and cool winters. Uniform sized lilium bulbs (12/14 size) were selected for the experimentation. Before planting, bulbs were treated in solution comprising of Bavistin (0.1\%) and Dithane M-45 (0.2\%) for 30 minutes. LA hybrid cultivars; 'Batistero' and 'Courier' were selected for the studies. Used different growing media and their combinations, $\mathrm{M}_{1 \text { - }}$ sand+soil+FYM, (1:1:1; v/v), $\mathbf{M}_{2-}$ sand+soil+FYM $(2: 1: 1 ; \mathrm{v} / \mathrm{v}), \mathrm{M}_{3-}$ cocopeat+FYM $\quad(1: 1 ; \mathrm{v} / \mathrm{v}), \quad \mathrm{M}_{4-}$ cocopeat+soil+FYM $(1: 1: 1 ; \mathrm{v} / \mathrm{v}), \quad \mathrm{M}_{5}$ $\mathrm{M}_{1}+$ cocopeat $\quad(1: 1 ; \mathrm{v} / \mathrm{v}), \quad \mathrm{M}_{6}$ $\begin{array}{llll}\mathrm{M}_{1}+\text { vermicompost } & (2: 1 ; \mathrm{v} / \mathrm{v}), & \mathrm{M}_{7-} & \mathrm{M}_{1}+\end{array}$ vermicompost + cocopeat $(2: 1: 1 ; \mathrm{v} / \mathrm{v})$. Number of replications three and Completely Randomized Design (Factorial) were used.

\section{Results and Discussion}

\section{Days taken for bulb sprouting}

Data in table 1 shows that the cultivars did not differ significantly from each other, with respect to number of days taken for sprouting (Appendix-II). The bulbs of cultivar 'Batistero' however, sprouted earlier (28.94 days) as compared to 'Courier' (29.25 days).

In general, media amendments seems to have a positive effect on bulb sprouting with earlier sprouting observed in all the amended media over $\mathrm{M}_{1}$ (sand + soil + FYM; 1:1:1; v/v). Earliest sprouting (27.31 days) was, however, observed when bulbs of Lilium cultivars were planted in growing medium containing $\mathrm{M}_{1}+$ vermicompost + cocopeat; $2: 1: 1 ; \mathrm{v} / \mathrm{v}\left(\mathrm{M}_{7}\right)$. On the other hand, maximum delay in sprouting (30.32 days) was observed in $\mathrm{M}_{1}$ (sand + soil + FYM; 1:1:1; v/v). It is also evident from the interaction data that bulbs of cv. 'Batistero' sprouted at the earliest (26.33 days) when grown in $\mathbf{M}_{7}\left(\mathrm{M}_{1}+\right.$ vermicompost + cocopeat; $2: 1: 1 ; \mathrm{v} / \mathrm{v})$.

In cv. 'Courier' also earliest sprouting (28.30 days) was affected by the same medium. In contrast, maximum days for sprouting were taken by bulbs of 'Batistero' (30.75 days) grown on $\mathrm{M}_{1}$ (sand + soil + FYM; $1: 1: 1 ; \mathrm{v} / \mathrm{v}$ ) and found to be at par when cv. 'Courier' grown in $\mathrm{M}_{2}$ medium (30.25 days).

The present findings show that days taken to sprouting in lilium LA hybrids were influenced by media composition. Earliest sprouting recorded in cultivars 'Batistero' (28.94 days) and 'Courier' (29.25 days) in bulbs grown in $\mathrm{M}_{7}$ i.e. $\mathrm{M}_{1}+$ vermicompost + cocopeat could be attributed to the fact that soil amended with cocopeat and sand has resulted in optimum porosity and aeration providing favourable conditions for tender sprout to grow and favouring early sprouting. Early sprouting in cocopeat based medium was also reported by Lyngdoh et al., (2015) during scale propagation in lilium. Better sprouting of bulbs of Amaryllis belladonna was also observed in medium containing mushroom compost in comparison to control i.e. simple soil (Bostan et al., 2014).

\section{Plant height (cm)}

A perusal of data showed in table 2 reveals that plants of cv. 'Batistero' attained more height $(92.02 \mathrm{~cm})$ as compared to 'Courier' $(83.14 \mathrm{~cm})$. 
Among different growing media, maximum plant height $(89.24 \mathrm{~cm})$ was observed in $\mathrm{M}_{1}$ (sand +soil + FYM; 1:1:1; v/v). Similar results were, however, observed when bulbs were grown in $\mathrm{M}_{2}(87.74 \mathrm{~cm})$ (sand + soil + FYM; 2:1:1; v/v), $\mathrm{M}_{3}(87.73 \mathrm{~cm})$ (cocopeat + FYM; $1: 1 ; \mathrm{v} / \mathrm{v}), \mathrm{M}_{4}(88.64 \mathrm{~cm})$ (cocopeat + soil + FYM; 1:1:1; v/v) and $\mathrm{M}_{7}(87.31 \mathrm{~cm})$ $\left(\mathrm{M}_{1}+\right.$ vermicompost + cocopeat; $\left.2: 1: 1 ; \mathrm{v} / \mathrm{v}\right)$. On the other hand, minimum plant height $(85.80 \mathrm{~cm})$ was recorded when bulbs were grown in $\mathrm{M}_{5}\left(\mathrm{M}_{1}+\right.$ cocopeat; $\left.1: 1 ; \mathrm{v} / \mathrm{v}\right)$.

Data pertaining to interaction between cultivars and growing media shows that bulbs of LA hybrid 'Batistero' grown in $\mathrm{M}_{1}$ (sand + soil + FYM; 1:1:1; v/v) recorded maximum plant height $(93.85 \mathrm{~cm})$. Other media viz. $\mathrm{M}_{3}$ $(92.65 \mathrm{~cm})$ (cocopeat + FYM; 1:1; v/v), $\mathrm{M}_{4}$ $(93.71 \mathrm{~cm})$ (cocopeat + soil + FYM; 1:1:1; $\mathrm{v} / \mathrm{v}), \mathrm{M}_{5}(91.38 \mathrm{~cm})\left(\mathrm{M}_{1}+\right.$ cocopeat; $\left.1: 1 ; \mathrm{v} / \mathrm{v}\right)$, $\mathrm{M}_{6}(91.28 \mathrm{~cm}) \quad\left(\mathrm{M}_{1}+\right.$ Vermicompost; 2:1; $\mathrm{v} / \mathrm{v})$ and $\mathrm{M}_{7}(92.33 \mathrm{~cm})\left(\mathrm{M}_{1}+\right.$ vermicompost + cocopeat; 2:1:1; v/v) also gave similar results in LA hybrid 'Batistero'. In case of cv. 'Courier', maximum plant height $(86.52 \mathrm{~cm})$ was observed when grown in $\mathrm{M}_{2}$ (sand + soil + FYM; 2:1:1; v/v). In contrast, plant height was recorded to be minimum when cv. 'Courier' $(80.24 \mathrm{~cm})$ was grown in $\mathrm{M}_{5}\left(\mathrm{M}_{1}+\right.$ cocopeat $(1: 1, \mathrm{v} / \mathrm{v})$.

A significant variation was observed between cultivars for plant height. It can be attributed to the genotypic difference among the cultivars.

Maximum plant height in case of 'Batistero' $\left(93.85 \mathrm{~cm}\right.$ ) was recorded in $\mathrm{M}_{1}$ (sand +soil + FYM; $1: 1: 1 ; \mathrm{v} / \mathrm{v}$ ) whereas in 'Courier' it was maximum $\left(86.52 \mathrm{~cm}\right.$ ) in $\mathrm{M}_{2}$ (sand + soil + FYM; $2: 1: 1 ; v / v)$. Lilium can be grown on a large number of substrates and therefore, showed better performance on soil amended with sand and FYM. However, visual observations show that although maximum plant height was obtained in $\mathrm{M}_{1}$ and $\mathrm{M}_{2}$ media but the cut stems were thin and were less qualitative.

The interaction data shows that the maximum plant height obtained in both the cultivars was however found to be at par with almost all other growing media. Increase in plant height in media amended with different constituents has also been reported by Singh (2013) in Alstroemeria.

\section{Number of leaves per plant}

A perusal of data in table 3 reveals that the cultivars showed significant difference among them for number of leaves per plant. More number of leaves per plant was recorded in cultivar 'Courier' (42.09) in comparison to 'Batistero' (40.10).

Numbers of leaves per plant were significantly affected by different growing media also. Bulbs grown in $\mathrm{M}_{7}\left(\mathrm{M}_{1}+\right.$ vermicompost + cocopeat; $2: 1: 1 ; \mathrm{v} / \mathrm{v})$ resulted in maximum number of leaves per plant (46.10). Similar results were, however, obtained in $\mathrm{M}_{6}$ (45.69) ( $\mathrm{M}_{1}+$ vermicompost; $2: 1 ; \mathrm{v} / \mathrm{v})$ also. On the other hand, numbers of leaves per plant (35.57) were recorded minimum when bulbs were grown in sand + soil + FYM; 1:1:1; v/v $\left(\mathrm{M}_{1}\right)$.

Data pertaining to interaction between cultivars and growing media shows that maximum number of leaves per plant (47.76) was found when bulbs of LA hybrid 'Courier' were grown in $\mathrm{M}_{7}\left(\mathrm{M}_{1}+\right.$ vermicompost + cocopeat; $2: 1: 1 ; \mathrm{v} / \mathrm{v})$. It was, however, found to be at par with bulbs grown in $\mathrm{M}_{\mathbf{6}}(47.25)\left(\mathrm{M}_{1}\right.$ + vermicompost; $2: 1$; v/v). In case of cv. 'Batistero' also maximum number of leaves per plant (44.45) was found when bulbs were grown in $\left(\mathrm{M}_{7}\right)$. In contrast, number of leaves was observed minimum when cv. 'Batistero' 
(33.66) was grown in sand + soil + FYM; $1: 1: 1 ; \mathrm{v} / \mathrm{v}\left(\mathrm{M}_{1}\right)$.

The variation among cultivars for number of leaves per plant also seems to be a genotypic character. In the present studies, media amended with vermicompost proved most superior for enhancing number of leaves per plant. Lilium bulbs grown on $\mathrm{M}_{7}\left(\mathrm{M}_{1}+\right.$ vermicompost + cocopeat; 2:1:1; v/v) produced maximum number of leaves per plant irrespective of cultivars. Similar results were obtained by growing the bulbs in $\mathrm{M}_{6}$ $\left(\mathrm{M}_{1}+\right.$ vermicompost; 2:1; $\left.\mathrm{v} / \mathrm{v}\right)$. Vermicompost is known to have increased water holding capacity and enhanced nutrient uptake (Tomati et al., 1988; Atiyesh et al., 2002; Bachman and Metzger, 2008). Addition of cocopeat along with vermicompost as a source of organic nutrients augmented the vegetative growth in lilium. Increased number of leaves on media amended with vermicompost has also been reported by Moghadam et al., (2012) in lilium Asiatic hybrid 'Navona'.

Maximum number of leaves with larger leaf area was also found in lilium cultivars grown on medium amended with cocopeat (Nikrazm et al., 2011). Jong et al., (2002) also reported highest number of leaves on a media containing rice hull, sawdust and pine bark $(1: 1: 1 ; \mathrm{v} / \mathrm{v})$ in lilium cv. 'Orange Pixie'

\section{Number of days taken for basal bud to show colour}

An appraisal of data in table 4 elucidates that cultivars differ significantly from each other with respect to number of days taken for basal bud to show colour with earlier coloured bud (121.20 days) observed in cv. 'Courier' as compared to 'Batistero' (122.20 days).

Among different growing media, earliest coloured bud (116.72 days) was observed when bulbs of Lilium cultivars were planted in medium containing $\mathrm{M}_{1}+$ vermicompost + cocopeat; 2:1:1; v/v $\left(\mathrm{M}_{7}\right)$. In contrast, maximum delay in basal bud to show colour was observed in $\mathrm{M}_{4}$ (124.68 days) i.e. when bulbs were grown in cocopeat + soil + FYM; $1: 1: 1 ; \mathrm{v} / \mathrm{v}$.

It is also evident from the interaction data that bulbs of cv. 'Courier' showed coloured bud at the earliest (115.43 days) when grown in $\mathrm{M}_{7}$ $\left(\mathrm{M}_{1}+\right.$ vermicompost + cocopeat; $\left.2: 1: 1 ; \mathrm{v} / \mathrm{v}\right)$.

Earliest coloured bud (118.00days) in case of 'Batistero' was also obtained in the same medium $\left(\mathrm{M}_{7}\right)$. In contrast, maximum days for basal bud to show colour was observed by bulbs of 'Batistero' (124.75 days) grown in $\mathrm{M}_{4}($ cocopeat + soil + FYM; 1:1:1; v/v).

Lesser number of days was taken by cultivar 'Courier' (121.10 days) for coloured bud formation than 'Batistero' (122.20 days). It could be attributed to the genotypic differences among cultivars.

In our studies earliest coloured bud was observed in bulbs grown in $\mathrm{M}_{7}$ containing $\mathrm{M}_{1}$ + vermicompost + cocopeat, irrespective of the cultivar. As discussed earlier growing medium $\mathrm{M}_{7}$ containing cocopeat and vermicompost provided most optimum conditions for various growth parameters, producing more number of leaves per plant (Table 3) with maximization of photosynthesis which helped in maintaining optimum health of the plant.

Further, early sprouting observed in $\mathrm{M}_{7}$ (Table 1) also resulted in early bud development as compared to other media. Our results are in close conformity with the findings of, (Wazir et al., 2009) who reported earliest flower bud formation in Alstroemeria grown in soil + sand + cocopeat + vermicopmost + FYM $(1: 1: 1: 1: 1, \mathrm{v} / \mathrm{v})$. 
Earliest bud visibility and colour development were also recorded in four LA lilium cultivars viz. 'Brunello', 'Nova Cento', 'Romano' and 'Elite' in medium amended with cocopeat in comparison to natural soil media ( Rani et al., 2005).

\section{Number of days taken to flowering}

Data presented in table 5 elucidates that cultivars, growing media and their interaction had a significant effect on number of days taken to flowering in LA hybrid cultivars. Earlier flowering was observed in cultivar 'Courier' (123.94 days) as compared to 'Batistero' (125.42 days).

Earliest flowering (123.94 days) was also observed when bulbs of Lilium cultivars were planted in medium containing $\mathrm{M}_{1}+$ vermicompost + cocopeat; 2:1:1; v/v $\left(\mathrm{M}_{7}\right)$. Similar results were, however, obtained with bulbs grown in $\mathrm{M}_{1}$ (125.17 days) (sand + soil + FYM; 1:1:1; v/v), M2 (124.00 days) (sand + soil + FYM; 2:1:1; v/v), $\mathrm{M}_{5}$ (124.67 days) $\left(\mathrm{M}_{1}\right.$ + cocopeat; $1: 1 ; \mathrm{v} / \mathrm{v})$ and $\mathrm{M}_{6}(125.30$ days) $\left(\mathrm{M}_{1}+\right.$ vermicompost; $\left.2: 1 ; \mathrm{v} / \mathrm{v}\right)$. On the other hand, maximum delay in flowering (126.52 days) was noted when bulbs were grown in cocopeat + soil + FYM; 1:1:1; v/v $\left(\mathrm{M}_{4}\right)$.

It is also clear from the interaction data that earliest flowering (119.83 days) was observed in cv. 'Courier' when grown in $\mathrm{M}_{7}\left(\mathrm{M}_{1}+\right.$ vermicompost + cocopeat; $2: 1: 1 ; \mathrm{v} / \mathrm{v})$. In case of cultivar 'Batistero' also $\mathrm{M}_{7}$ effected earliest flowering (122.17days). In contrast, maximum days taken to flowering were recorded by bulbs of 'Batistero' (127.53 days) grown in $\mathrm{M}_{4}$ (cocopeat + soil + FYM; 1:1:1; $\mathrm{v} / \mathrm{v})$.

The genotypic variation among cultivars for days to flowering was also reflected in the data, with cv. 'Courier' showing earlier flowering (123.9) than 'Batistero' (125.42 days).
Flowering was significantly hastened in $\mathbf{M}_{7}$ $\left(\mathrm{M}_{1}+\right.$ vermicompost + cocopeat; $\left.2: 1: 1 ; \mathrm{v} / \mathrm{v}\right)$ over all other treatments. It is directly correlated with earliest colour bud formation (Table 4) in this medium. It can also be attributed to more vegetative growth and leaf number per plant in the medium which contributed significantly to accumulation of photosynthates and in turn inducing optimum growth, early bud formation and flowering.

Seyedi et al., 2012, who carried out experiment on effect of growing media on LA hybrid lilies concluded that cocopeat as medium amendment owing to its appropriate physical and chemical properties probably makes better growth of plants to decrease days from planting to reproductive stage.

\section{Stem length (cm)}

Data presented in table 6 reveals that more stem length was attained in cv. 'Batistero' $(71.71 \mathrm{~cm})$ as compared to cv. 'Courier' $(63.74 \mathrm{~cm})$.

Maximum stem length $(68.82 \mathrm{~cm})$ was also recorded when liliums were grown in $\mathbf{M}_{2}$ (sand + soil + FYM; 2:1:1; v/v). Similar results were obtained with the bulbs grown in $\mathrm{M}_{1}(68.35 \mathrm{~cm})$ (sand + soil + FYM; 1:1:1; v/v), $M_{4}(68.38 \mathrm{~cm})$ (cocopeat + soil + FYM; $1: 1: 1 ; \mathrm{v} / \mathrm{v})$ and $\mathrm{M}_{7}(68.66 \mathrm{~cm}) \quad\left(\mathrm{M}_{1}+\right.$ vermicompost + cocopeat; $2: 1: 1 ; \mathrm{v} / \mathrm{v})$. In contrast, stem length was found minimum $(66.32 \mathrm{~cm})$ in $\mathrm{M}_{3}$ (cocopeat + FYM; 1:1; v/v).

Interaction data shows that bulbs of LA hybrid 'Batistero' grown in $\mathrm{M}_{1}$ (sand + soil + FYM; 1:1:1; v/v) recorded maximum stem length $(73.62 \mathrm{~cm})$. It was, however, found to be statistically at par with stem length obtained when bulbs of 'Batistero' were grown in $\mathbf{M}_{\mathbf{6}}(72.66 \mathrm{~cm})\left(\mathrm{M}_{1}+\right.$ vermicompost; $2: 1 ; \mathrm{v} / \mathrm{v})$. 
In case of LA hybrid 'Courier' highest stem length $(66.45 \mathrm{~cm})$ was obtained when bulbs were grown in media containing sand + soil + FYM; $2: 1: 1 ;$ v/v i.e. $\mathrm{M}_{2}$. On the other hand, stem length was recorded minimum when bulbs of cv. 'Courier' $(60.91 \mathrm{~cm})$ were grown in $\mathrm{M}_{5}\left(\mathrm{M}_{1}+\right.$ cocopeat; $\left.1: 1 ; \mathrm{v} / \mathrm{v}\right)$.

More stem length observed in cv. 'Batistero' in comparison to Courier could be attributed to corresponding higher plant height (Table 2) in it.

Growing media have also affected the stem length considerably. Maximum stem length in case of 'Batistero' is obtained in $\mathrm{M}_{1}$ (sand + soil + FYM; 1:1:1; v/v) whereas the same effect in 'Courier' was induced by $\mathrm{M}_{2}$ (sand + soil + FYM; 2:1:1; v/v). Maximum stem length in the present studies is directly related to the corresponding maximum plant height (Table 2) observed in these media or may be due to more intermodal length.

Similar results were, however, obtained in other growing media also which shows the positive effects of media amendments on plant growth and development.

\section{Bud length (cm)}

It is apparent from table 7 that longer buds were observed in cv. 'Batistero' $(12.82 \mathrm{~cm})$ as compared to 'Courier' $(9.65 \mathrm{~cm})$. Maximum bud length $(13.94 \mathrm{~cm})$ was observed in growing medium $\mathrm{M}_{1}$ (sand + soil + FYM; $1: 1: 1 ; \mathrm{v} / \mathrm{v})$. On the other hand, lowest bud length $(9.95 \mathrm{~cm})$ was found when bulbs were grown in $\mathrm{M}_{3}$ (Cocopeat + FYM; 1:1; v/v).

Interaction of cultivars with growing media shows that highest bud length $(15.32 \mathrm{~cm})$ was recorded when bulbs of LA hybrid 'Batistero' were grown in $\mathrm{M}_{1}$ (sand + soil + FYM; 1:1:1; $\mathrm{v} / \mathrm{v})$.The same medium $\mathrm{M}_{1}$ effected maximum bud length $(12.55 \mathrm{~cm})$ in cv. 'Courier' also. In contrast, minimum bud length was observed when bulbs of cv. 'Courier' $(8.03 \mathrm{~cm})$ were grown in $\mathrm{M}_{3}$ (cocopeat + FYM; 1:1; v/v).

Cultivar 'Batistero' showed superiority for bud length over 'Courier' which could again be attributed to the genotypic differences among them. Growing of bulbs in $\mathrm{M}_{1}$ (sand + soil + FYM; 2:1:1; v/v) has resulted in the production of maximum number of flowers per spike in both the cultivars. Bud length has direct correlation with number of flowers per spike.

The carbohydrates synthesized and accumulated by the plants during vegetative phase are being diverted for the development of flowers on the plant. The carbohydrates produced in the plants raised on $\mathrm{M}_{1}$ develop were directed for the production of lesser number of buds/spike (Table 8) making the buds larger and healthier in comparison to other growing media where number of buds/spike were more.

Our findings are in close conformity with De Hertogh, 1989 who reported that flower bud (5.59). On the other hand, minimum number of flowers per spike (3.53) was recorded in $\mathrm{M}_{1}$ (sand + soil + FYM; 1:1:1; v/v).

\section{Number of flowers per spike}

An appraisal of data in table 8 elucidates that lilium cultivars differ significantly from each other with respect to number of flowers per spike. More number of flowers per spike was recorded in cultivar 'Courier' (4.57) as compared to cv 'Batistero' (4.20).

Number of flowers per spike was significantly affected by different growing media also. Lilium bulbs grown in $\mathrm{M}_{7}\left(\mathrm{M}_{1}+\right.$ vermicompost + cocopeat; $2: 1: 1 ; \mathrm{v} / \mathrm{v})$ gave maximum number of flowers/spike (5.59). On the other hand, minimum number of flowers per spike (3.53) were recorded in $\mathrm{M}_{1}$ (sand+soil+FYM; 1:1:1;v/v). 
Interaction data was found to be non significant (Appendix-II). However, largest number of flowers per spike (6.08) was, however, recorded when bulbs of LA hybrid 'Courier' were grown in $\mathrm{M}_{7}\left(\mathrm{M}_{1}+\right.$ vermicompost + cocopeat; $2: 1: 1 ; \mathrm{v} / \mathrm{v})$. In case of cv. 'Batistero' also maximum number of flowers per spike (5.10) was found in same medium $\left(\mathrm{M}_{7}\right)$. On the other hand, minimum number of flowers per spike was obtained when bulbs of 'Batistero' (3.32) were planted in $\mathrm{M}_{3}$ (cocopeat + FYM; 1:1; v/v).

More number of flowers per spike was obtained in cv. 'Courier' in comparison to 'Batistero'. This may be due genetic variation among cultivars.

Among growing media, bulbs grown in $\mathbf{M}_{7}$ medium produced more number of flowers per spike in comparison to all other media. Optimum growing conditions provided by the medium amended with vermicompost and cocopeat helped to optimise the plant health resulting in the production of more number of flowers/spike.

Vermicompost is a sustainable source of macro and micro nutrients and has a considerable potential for improving plant growth significantly when used as soil amendments in horticultural crops (Sahni et al., 2008). In a similar a study on Asiatic hybrid lily 'Navona', Moghadam et al., 2012 also reported more number of flowers per spike in medium amended with different doses of vermicompost.

\section{Size of flower $(\mathrm{cm})$}

A perusal of data in table 9 reveals that variation due to cultivars, growing media and their interaction had a significant effect on flower size $(\mathrm{cm})$ in LA hybrid cultivars. Larger flowers were obtained in cv. 'Batistero' (16.15 cm) as compared to $\mathrm{cv}$. 'Courier' (15.47 cm).
Among different growing media, larger sized flower $(17.64 \mathrm{~cm})$ was observed in $\mathrm{M}_{1}$ (sand + soil + FYM; 1:1:1; v/v) medium. In contrast, size of flower $(14.00 \mathrm{~cm})$ was recorded minimum in lilium grown in $\mathbf{M}_{3}$ (cocopeat + FYM; 1:1; v/v) medium.

Interaction between cultivar and growing media shows that maximum flower size $(18.12 \mathrm{~cm})$ was obtained when bulbs of LA hybrid 'Batistero' were grown in $\mathrm{M}_{1}$ medium ( sand + soil + FYM; 1:1:1; v/v).

The same medium $\left(\mathrm{M}_{1}\right)$ effected maximum flower size $(17.17 \mathrm{~cm})$ in 'Courier' also. In contrast, smallest flowers $(13.83 \mathrm{~cm})$ were obtained in 'Courier' grown in $\mathrm{M}_{4}$ (cocopeat + soil + FYM; 1:1:1; v/v) and 'Batistero' grown in $\mathrm{M}_{3}$ (cocopeat $+\mathrm{FYM} ; 1: 1 ; \mathrm{v} / \mathrm{v}$ ) and $\mathrm{M}_{6}\left(\mathrm{M}_{1}+\right.$ vermicompost; $\left.2: 1 ; \mathrm{v} / \mathrm{v}\right)$.

Larger flowers were produced by $\mathrm{cv}$. 'Batistero' as compared to 'Courier'. In both the cultivars, flowers of maximum diameter were obtained when bulbs were grown in $\mathrm{M}_{1}$ (sand + soil + FYM; 1:1:1; v/v).

Larger flower size obtained in $\mathrm{M}_{1}$ in the present studies could be attributed to the corresponding larger bud size observed in this medium.

As already discussed in table 7 and according to De Hertogh (1989) flower size is inversely related to number of flowers on a spike.

\section{Duration of flowering (days)}

Data presented in the table 10 reveals that variation due to cultivars, growing media and their interaction had a significant effect on duration of flowering (days) in LA hybrid cultivars. Duration of flowering was recorded more in cv. 'Courier' (28.72 days) as compared to 'Batistero' (26.38 days). Longest duration of flowering (32.00 days) was also obtained when bulbs were grown in $\mathrm{M}_{7}\left(\mathrm{M}_{1}+\right.$ 
vermicompost + cocopeat; $2: 1: 1 ; \mathrm{v} / \mathrm{v})$. On the other hand, bulbs grown in $\mathrm{M}_{4}$ (cocopeat + soil + FYM; 1:1:1; v/v) recorded minimum flowering duration (24.50 days).

Interaction between cultivars and growing media reveals that longest duration of flowering (32.00 days) was found when bulbs of LA hybrid 'Courier' and 'Batistero' were grown in $\mathrm{M}_{7} \quad\left(\mathrm{M}_{1}+\right.$ vermicompost + cocopeat; 2:1:1; v/v). However, shortest duration of flowering (21.33 days) was recorded when bulbs of 'Batistero' were grown in $\mathrm{M}_{3}$ (cocopeat + FYM; $1: 1$; v/v).

Growing of lilium bulbs in $\mathrm{M}_{7}$ i.e. sand + soil + FYM $(1: 1: 1, \mathrm{v} / \mathrm{v})$ amended with vermicompost and cocopeat resulted in maximum flowering duration in lilium cultivars 'Batistero' and 'Courier'. Duration of flowering can be correlated to number of flowers per spike (Table 8) in the treatment. Growing of lilium bulbs in $\mathrm{M}_{7}$ produced maximum number of flowers per spike which lasted for longer duration in comparison to plants raised on other media producing less number of flowers per spike.

Our results are also supported by the finding of Wazir et al., (2009) in Alstroemeria, who observed that maximum duration of flowering in two consecutive flushes were obtained in crop grown on medium containing sand + soil + cocopeat + vermicompost + FYM $(1: 1: 1: 1, \mathrm{v} / \mathrm{v})$. Prisa et al., (2011) found an improvement in flower quality and longevity in cut stems of Asiatic hybrid grown on new amendments over the traditional substrate.

\section{Weight of stem (g)}

It is apparent from the table 11 that the cultivars differ significantly from each other with respect to weight of stem in LA hybrid lilies. More stem weight was found in cultivar 'Batistero' (82.23 g) as compared to 'Courier' (50.98 g).
Weight of stem was significantly affected by different growing media. Heavier cut stems $(73.40 \mathrm{~g})$ were obtained from bulbs grown in $\mathrm{M}_{6}\left(\mathrm{M}_{1}+\right.$ vermicompost; $\left.2: 1 ; \mathrm{v} / \mathrm{v}\right)$. Similar results were, however, recorded when bulbs were grown in $\mathrm{M}_{7}(73.04 \mathrm{~g})\left(\mathrm{M}_{1}+\right.$ vermicompost + cocopeat; $2: 1: 1 ; \mathrm{v} / \mathrm{v})$. On the other hand, minimum stem weight $(60.10 \mathrm{~g})$ was recorded in bulbs grown in $\mathrm{M}_{4}$ (cocopeat + soil + FYM; 1:1:1; v/v).

Interaction between cultivars and growing media was found to be non significant (Appendix-II). Data shows that highest weight of stem (88.92 g) was obtained when bulbs of LA hybrid 'Batistero' were grown in $\mathrm{M}_{7}\left(\mathrm{M}_{1}+\right.$ vermicompost + cocopeat; 2:1:1; $\mathrm{v} / \mathrm{v}$ ). In case of cv. 'Courier' maximum stem weight $(57.92 \mathrm{~g})$ was recorded when bulbs were grown in $\mathrm{M}_{6}\left(\mathrm{M}_{1}+\right.$ vermicompost; 2:1; $\mathrm{v} / \mathrm{v})$. In contrast, minimum stem weight was observed when bulbs of cv. 'Courier' (44.64 g) were grown in $\mathrm{M}_{2}$ (sand + soil + FYM; $2: 1: 1 ; \mathrm{v} / \mathrm{v})$.

Heavier stems were obtained in 'Batistero' as compared to cv. 'Courier', which seems to be a genetic character. Among growing media, heaviest stems were obtained from the crop grown on $\mathrm{M}_{6}$ i.e $\mathrm{M}_{1}+$ vermicompost (2:1, $\mathrm{v} / \mathrm{v})$ followed by $\mathrm{M}_{7}$ is $\left(\mathrm{M}_{1}+\right.$ vermicompost + cocopeat; $2: 1: 1 ; \mathrm{v} / \mathrm{v})$.

The superiority of vermicompost amended medium for improvement of various vegetative and flower parameters by providing optimum growing conditions might be responsible for production of heavier stems in this medium. Better quality cut stems in Oriental lilies have been reported in media containing cocopeat in combination with other constituents (Treder, 2005).

\section{Vase life (days)}

A perusal of data in table 12 reveals that variation due to cultivars, growing media and 
their interaction had a significant effect on vase life (days) in LA hybrid cultivars. Cut flowers of cv. 'Batistero' lasted longer in vases (12.88 days) in comparison to 'Courier' (11.93 days).

Table.1 Effect of growing media on days taken for bulb sprouting of LA hybrid cultivars 'Batistero' and 'Courier'

\begin{tabular}{|c|c|c|c|}
\hline \multirow[t]{2}{*}{ Growing media } & \multicolumn{2}{|c|}{ Cultivars } & \multirow{2}{*}{ Mean } \\
\hline & Batistero & Courier & \\
\hline $\mathbf{M}_{1-\text {-sand+soil+FYM, }(1: 1: 1, \mathrm{v} / \mathrm{v})}$ & 30.75 & 29.89 & 30.32 \\
\hline $\mathbf{M}_{2}$-sand+soil+FYM $(2: 1: 1, \mathrm{v} / \mathrm{v})$ & 27.50 & 30.25 & 28.88 \\
\hline $\mathbf{M}_{3}$-cocopeat+FYM $(1: 1, \mathrm{v} / \mathrm{v})$ & 29.86 & 28.33 & 29.10 \\
\hline $\mathbf{M}_{4}$-cocopeat+soil+FYM $(1: 1: 1, \mathrm{v} / \mathrm{v})$ & 29.14 & 29.17 & 29.15 \\
\hline $\mathbf{M}_{5}-\mathrm{M}_{1}+$ cocopeat $(1: 1, \mathrm{v} / \mathrm{v})$ & 29.44 & 29.11 & 29.28 \\
\hline $\mathbf{M}_{\mathbf{6}-} \mathbf{M}_{1}+$ vermicompost $(2: 1, \mathrm{v} / \mathrm{v})$ & 29.53 & 29.67 & 29.60 \\
\hline $\mathbf{M}_{7}-\mathbf{M}_{1}+$ vermicompost + cocopeat $(2: 1: 1, \mathrm{v} / \mathrm{v})$ & 26.33 & 28.30 & 27.31 \\
\hline Mean & 28.94 & 29.25 & - \\
\hline
\end{tabular}

$\mathrm{CD}_{0.05}$ for:

$\begin{array}{lc}\text { Cultivars } & \text { NS } \\ \text { Growing media } & 0.80 \\ \text { Growing media x Cultivars } & 1.14\end{array}$

Table.2 Effect of growing media on plant height $(\mathrm{cm})$ of LA hybrid cultivars 'Batistero' and 'Courier'

\begin{tabular}{|c|c|c|c|}
\hline \multirow[t]{2}{*}{ Growing media } & \multicolumn{2}{|c|}{ Cultivars } & \multirow[t]{2}{*}{ Mean } \\
\hline & Batistero & Courier & \\
\hline $\mathbf{M}_{1}$-sand+soil+FYM, (1:1:1, v/v) & 93.85 & 84.62 & 89.24 \\
\hline $\mathbf{M}_{2}$-sand+soil+FYM $(2: 1: 1, \mathrm{v} / \mathrm{v})$ & 88.95 & 86.52 & 87.74 \\
\hline $\mathbf{M}_{3}$-cocopeat+FYM $(1: 1, \mathrm{v} / \mathrm{v})$ & 92.65 & 82.81 & 87.73 \\
\hline $\mathbf{M}_{4}$-cocopeat+soil+FYM $(1: 1: 1, \mathrm{v} / \mathrm{v})$ & 93.71 & 83.57 & 88.64 \\
\hline $\mathbf{M}_{5}-\mathrm{M}_{1}+$ cocopeat $(1: 1, \mathrm{v} / \mathrm{v})$ & 91.38 & 80.24 & 85.80 \\
\hline $\mathbf{M}_{\mathbf{6}} \mathbf{M}_{1}+$ vermicompost $(2: 1, \mathrm{v} / \mathrm{v})$ & 91.28 & 81.90 & 86.59 \\
\hline $\begin{array}{l}\mathbf{M}_{7^{-}} \quad \mathbf{M}_{1}+\text { vermicompost }+ \text { cocopeat } \\
(2: 1: 1, \mathrm{v} / \mathrm{v})\end{array}$ & 92.33 & 82.29 & 87.31 \\
\hline Mean & 92.02 & 83.14 & - \\
\hline \multicolumn{4}{|l|}{$\mathrm{CD}_{0.05}$ for: } \\
\hline Cultivars & 1.06 & & \\
\hline Growing media & 1.99 & & \\
\hline Growing media $\mathrm{x}$ Cultivars & 2.82 & & \\
\hline
\end{tabular}


Table.3 Effect of growing media on number of leaves/plant of LA hybrid cultivars 'Batistero' and 'Courier'

\begin{tabular}{|c|c|c|c|}
\hline \multirow[t]{2}{*}{ Growing media } & \multicolumn{2}{|c|}{ Cultivars } & \multirow[t]{2}{*}{ Mean } \\
\hline & Batistero & Courier & \\
\hline $\mathbf{M}_{1}$-sand+soil+FYM, $(1: 1: 1, \mathrm{v} / \mathrm{v})$ & 33.66 & 37.47 & 35.57 \\
\hline $\mathbf{M}_{2}$-sand+soil+FYM $(2: 1: 1, \mathrm{v} / \mathrm{v})$ & 37.33 & 38.99 & 38.16 \\
\hline $\mathbf{M}_{3}$-cocopeat+FYM $(1: 1, \mathrm{v} / \mathrm{v})$ & 38.24 & 39.55 & 38.90 \\
\hline $\mathbf{M}_{4}$-cocopeat+soil+FYM $(1: 1: 1, \mathrm{v} / \mathrm{v})$ & 40.33 & 40.99 & 40.66 \\
\hline $\mathbf{M}_{5}-\mathrm{M}_{1}+$ cocopeat $(1: 1, \mathrm{v} / \mathrm{v})$ & 42.57 & 42.61 & 42.59 \\
\hline $\mathbf{M}_{6-} \mathbf{M}_{1}+$ vermicompost $(2: 1, \mathrm{v} / \mathrm{v})$ & 44.14 & 47.25 & 45.69 \\
\hline $\mathbf{M}_{7}-\mathbf{M}_{1}+$ vermicompost + cocopeat $(2: 1: 1, \mathrm{v} / \mathrm{v})$ & 44.45 & 47.76 & 46.10 \\
\hline Mean & 40.10 & 42.09 & - \\
\hline $\begin{array}{l}\text { CD n п for: } \\
\text { Cultivars } \\
\text { Growing media } \\
\text { Growing media x Cultivars }\end{array}$ & $\begin{array}{l}0.71 \\
1.33 \\
1.89\end{array}$ & & \\
\hline
\end{tabular}

Table.4 Effect of growing media on number of days taken for basal bud to show colour of LA hybrid cultivars 'Batistero' and 'Courier'

\begin{tabular}{|c|c|c|c|}
\hline \multirow[t]{2}{*}{ Growing media } & \multicolumn{2}{|c|}{ Cultivars } & \multirow[t]{2}{*}{ Mean } \\
\hline & Batistero & Courier & \\
\hline $\mathbf{M}_{1}$-sand+soil+FYM, $(1: 1: 1, \mathrm{v} / \mathrm{v})$ & 124.61 & 121.87 & 123.24 \\
\hline $\mathbf{M}_{2}$-sand+soil+FYM $(2: 1: 1, \mathrm{v} / \mathrm{v})$ & 123.89 & 119.00 & 121.44 \\
\hline $\mathbf{M}_{3}$-cocopeat+FYM $(1: 1, \mathrm{v} / \mathrm{v})$ & 119.00 & 120.33 & 119.67 \\
\hline $\mathbf{M}_{4}$-cocopeat+soil+FYM $(1: 1: 1, \mathrm{v} / \mathrm{v})$ & 124.75 & 124.62 & 124.68 \\
\hline $\mathbf{M}_{5}-\mathrm{M}_{1}+$ cocopeat $(1: 1, \mathrm{v} / \mathrm{v})$ & 124.12 & 123.28 & 123.70 \\
\hline $\mathbf{M}_{6-} \mathbf{M}_{1}+$ vermicompost $(2: 1, \mathrm{v} / \mathrm{v})$ & 121.00 & 123.19 & 122.09 \\
\hline $\mathbf{M}_{7}-\mathbf{M}_{1}+$ vermicompost + cocopeat $(2: 1: 1, \mathrm{v} / \mathrm{v})$ & 118.00 & 115.43 & 116.72 \\
\hline Mean & 122.20 & $\mathbf{1 2 1 . 1 0}$ & - \\
\hline
\end{tabular}

$\mathrm{CD}_{0.05}$ for:

Cultivars $\quad 0.79$

Growing media $\quad 1.48$

Growing media x Cultivars $\quad 2.09$

Table.5 Effect of growing media on number of days taken to flowering of LA hybrid cultivars 'Batistero' and 'Courier'

\begin{tabular}{|c|c|c|c|}
\hline \multirow[t]{2}{*}{ Growing media } & \multicolumn{2}{|c|}{ Cultivars } & \multirow[t]{2}{*}{ Mean } \\
\hline & Batistero & Courier & \\
\hline $\mathbf{M}_{1}$-sand+soil+FYM, (1:1:1, v/v) & 126.51 & 123.83 & 125.17 \\
\hline $\mathbf{M}_{2}$-sand+soil+FYM $(2: 1: 1, \mathrm{v} / \mathrm{v})$ & 122.50 & 125.50 & 124.00 \\
\hline $\mathbf{M}_{3}$-cocopeat+FYM $(1: 1, \mathrm{v} / \mathrm{v})$ & 126.67 & 125.55 & 126.11 \\
\hline $\mathbf{M}_{4}$-cocopeat+soil+FYM $(1: 1: 1, \mathrm{v} / \mathrm{v})$ & 127.53 & 125.50 & 126.52 \\
\hline $\mathbf{M}_{5}-\mathrm{M}_{1}+$ cocopeat $(1: 1, \mathrm{v} / \mathrm{v})$ & 127.33 & 122.00 & 124.67 \\
\hline $\mathbf{M}_{6-} \mathbf{M}_{1}+$ vermicompost $(2: 1, \mathrm{v} / \mathrm{v})$ & 125.27 & 125.33 & 125.30 \\
\hline $\mathbf{M}_{7}-\mathbf{M}_{1}+$ vermicompost + cocopeat $(2: 1: 1, \mathrm{v} / \mathrm{v})$ & 122.17 & 119.83 & 123.94 \\
\hline Mean & $\mathbf{1 2 5 . 4 2}$ & 123.94 & - \\
\hline $\begin{array}{l}\text { CD n п for: } \\
\text { Cultivars } \\
\text { Growing media } \\
\text { Growing media x Cultivars }\end{array}$ & $\begin{array}{l}0.85 \\
1.59 \\
2.24\end{array}$ & & \\
\hline
\end{tabular}


Table.6 Effect of growing media on stem length $(\mathrm{cm})$ of LA hybrid cultivars 'Batistero' and 'Courier'

\begin{tabular}{|c|c|c|c|}
\hline \multirow[t]{2}{*}{ Growing media } & \multicolumn{2}{|c|}{ Cultivars } & \multirow[t]{2}{*}{ Mean } \\
\hline & Batistero & Courier & \\
\hline $\mathbf{M}_{1}$-sand+soil+FYM, $(1: 1: 1, \mathrm{v} / \mathrm{v})$ & 73.62 & 63.08 & 68.35 \\
\hline $\mathbf{M}_{2}$-sand+soil+FYM $(2: 1: 1, \mathrm{v} / \mathrm{v})$ & 71.19 & 66.45 & 68.82 \\
\hline $\mathbf{M}_{3}$-cocopeat+FYM $(1: 1, \mathrm{v} / \mathrm{v})$ & 69.19 & 63.45 & 66.32 \\
\hline $\mathbf{M}_{4}$-cocopeat+soil+FYM $(1: 1: 1, \mathrm{v} / \mathrm{v})$ & 72.23 & 64.52 & 68.38 \\
\hline $\mathbf{M}_{5}-\mathrm{M}_{1}+$ cocopeat $(1: 1, \mathrm{v} / \mathrm{v})$ & 71.85 & 60.91 & 66.38 \\
\hline $\mathbf{M}_{6-} \mathbf{M}_{1}+$ vermicompost $(2: 1, \mathrm{v} / \mathrm{v})$ & 72.66 & 61.72 & 67.19 \\
\hline $\mathbf{M}_{7}-\mathbf{M}_{1}+$ vermicompost + cocopeat $(2: 1: 1, \mathrm{v} / \mathrm{v})$ & 71.26 & 66.07 & 68.66 \\
\hline Mean & 71.71 & 63.74 & - \\
\hline \multicolumn{4}{|l|}{$\mathrm{CD}_{0.05}$ for: } \\
\hline Cultivars & 0.41 & & \\
\hline Growing media & 0.77 & & \\
\hline Growing media $\mathrm{x}$ Cultivars & 1.09 & & \\
\hline
\end{tabular}

Table.7 Effect of growing media on bud length $(\mathrm{cm})$ of LA hybrid cultivars 'Batistero' and 'Courier'

\begin{tabular}{|c|c|c|c|}
\hline \multirow[t]{2}{*}{ Growing media } & \multicolumn{2}{|c|}{ Cultivars } & \multirow{2}{*}{ Mean } \\
\hline & Batistero & Courier & \\
\hline $\mathbf{M}_{1}$-sand+soil+FYM, $(1: 1: 1, \mathrm{v} / \mathrm{v})$ & 15.32 & 12.55 & 13.94 \\
\hline $\mathbf{M}_{2}$-sand+soil+FYM $(2: 1: 10, \mathrm{v} / \mathrm{v})$ & 12.98 & 10.98 & 11.98 \\
\hline $\mathbf{M}_{3}$-cocopeat+FYM $(1: 1, \mathrm{v} / \mathrm{v})$ & 11.86 & 8.03 & 9.95 \\
\hline $\mathbf{M}_{4}$-cocopeat+soil+FYM $(1: 1: 1, \mathrm{v} / \mathrm{v})$ & 12.65 & 8.25 & $\mathbf{1 0 . 4 5}$ \\
\hline $\mathbf{M}_{5}-\mathrm{M}_{1}+$ cocopeat $(1: 1, \mathrm{v} / \mathrm{v})$ & 12.83 & 10.62 & 11.73 \\
\hline $\mathbf{M}_{6}-\mathbf{M}_{1}+$ vermicompost $(2: 1, \mathrm{v} / \mathrm{v})$ & 11.93 & 8.46 & 10.20 \\
\hline $\mathbf{M}_{7}-\mathbf{M}_{1}+$ vermicompost + cocopeat $(2: 1: 1, \mathrm{v} / \mathrm{v})$ & 12.20 & 8.63 & $\mathbf{1 0 . 4 2}$ \\
\hline Mean & 12.82 & 9.65 & - \\
\hline \multicolumn{4}{|l|}{$\mathrm{CD}_{0.05}$ for: } \\
\hline Cultivars & 0.37 & & \\
\hline Growing media & 0.70 & & \\
\hline Growing media $\mathrm{x}$ Cultivars & 0.98 & & \\
\hline
\end{tabular}

Table.8 Effect of growing media on number of flowers/spike of LA hybrid cultivars 'Batistero' and 'Courier'

\begin{tabular}{|c|c|c|c|}
\hline \multirow[t]{2}{*}{ Growing media } & \multicolumn{2}{|c|}{ Cultivars } & \multirow[t]{2}{*}{ Mean } \\
\hline & Batistero & Courier & \\
\hline $\mathbf{M}_{1}$-sand+soil+FYM, $(1: 1: 1, \mathrm{v} / \mathrm{v})$ & 3.50 & 3.57 & 3.53 \\
\hline $\mathbf{M}_{2}$-sand+soil+FYM $(2: 1: 1, \mathrm{v} / \mathrm{v})$ & 3.89 & 3.95 & 3.92 \\
\hline $\mathbf{M}_{3}$-cocopeat+FYM $(1: 1, \mathrm{v} / \mathrm{v})$ & 3.32 & 4.00 & 3.66 \\
\hline $\mathbf{M}_{4}$-cocopeat+soil+FYM $(1: 1: 1, \mathrm{v} / \mathrm{v})$ & 3.48 & 3.90 & 3.70 \\
\hline $\mathbf{M}_{5}-\mathrm{M}_{1}+$ cocopeat $(1: 1, \mathrm{v} / \mathrm{v})$ & 4.11 & 4.52 & 4.32 \\
\hline $\mathbf{M}_{6-} \mathbf{M}_{1}+$ vermicompost $(2: 1, \mathrm{v} / \mathrm{v})$ & 4.78 & 4.95 & 4.87 \\
\hline $\mathbf{M}_{7}-\mathbf{M}_{1}+$ vermicompost + cocopeat $(2: 1: 1, \mathrm{v} / \mathrm{v})$ & 5.10 & 6.08 & 5.59 \\
\hline Mean & 4.20 & 4.57 & \\
\hline \multicolumn{4}{|l|}{$\mathrm{CD}_{0.05}$ for: } \\
\hline Cultivars & 0.21 & & \\
\hline Growing media & 0.39 & & \\
\hline Growing media $\mathrm{x}$ Cultivars & NS & & \\
\hline
\end{tabular}


Table.9 Effect of growing media on size of flower $(\mathrm{cm})$ of LA hybrid cultivars 'Batistero' and 'Courier'

\begin{tabular}{|c|c|c|c|}
\hline \multirow{2}{*}{ Growing media } & \multicolumn{2}{|c|}{ Cultivars } & \multirow{2}{*}{ Mean } \\
\hline & Batistero & Courier & \\
\hline $\mathbf{M}_{1}$-sand+soil+FYM, $(1: 1: 1, \mathrm{v} / \mathrm{v})$ & 18.12 & 17.17 & 17.64 \\
\hline $\mathbf{M}_{2}$-sand+soil+FYM $(2: 1: 1, \mathrm{v} / \mathrm{v})$ & 17.90 & 16.12 & $\mathbf{1 7 . 0 0}$ \\
\hline $\mathbf{M}_{3}$-cocopeat+FYM $(1: 1, \mathrm{v} / \mathrm{v})$ & 13.83 & 14.17 & 14.00 \\
\hline $\mathbf{M}_{4}$-cocopeat+soil+FYM $(1: 1: 1, \mathrm{v} / \mathrm{v})$ & 17.17 & 13.83 & 15.50 \\
\hline $\mathbf{M}_{5}-\mathrm{M}_{1}+$ cocopeat $(1: 1, \mathrm{v} / \mathrm{v})$ & 15.33 & 15.66 & 15.50 \\
\hline $\mathbf{M}_{\mathbf{6}-} \mathbf{M}_{1}+$ vermicompost $(2: 1, \mathrm{v} / \mathrm{v})$ & 13.83 & 15.33 & 14.58 \\
\hline $\mathbf{M}_{7}-\mathbf{M}_{1}+$ vermicompost + cocopeat $(2: 1: 1, \mathrm{v} / \mathrm{v})$ & 16.83 & 15.98 & 16.41 \\
\hline Mean & 16.15 & 15.47 & - \\
\hline
\end{tabular}

$\mathrm{CD}_{0.05}$ for:

Cultivars $\quad 0.25$

Growing media $\quad 0.47$

Growing media x Cultivars $\quad 0.67$

Table.10 Effect of growing media on duration of flowering (days) of LA hybrid cultivars 'Batistero' and 'Courier

\begin{tabular}{|c|c|c|c|}
\hline \multirow[t]{2}{*}{ Growing media } & \multicolumn{2}{|c|}{ Cultivars } & \multirow[t]{2}{*}{ Mean } \\
\hline & Batistero & Courier & \\
\hline $\mathbf{M}_{1}$-sand+soil+FYM, $(1: 1: 1, \mathrm{v} / \mathrm{v})$ & 25.33 & 26.67 & 26.00 \\
\hline $\mathbf{M}_{2}$-sand+soil+FYM $(2: 1: 1, \mathrm{v} / \mathrm{v})$ & 24.00 & 29.67 & 26.83 \\
\hline $\mathbf{M}_{3}$-cocopeat+FYM $(1: 1, \mathrm{v} / \mathrm{v})$ & 21.33 & 28.33 & 24.83 \\
\hline $\mathbf{M}_{4}$-cocopeat+soil+FYM $(1: 1: 1, \mathrm{v} / \mathrm{v})$ & 24.33 & 24.67 & 24.50 \\
\hline $\mathbf{M}_{5}-\mathrm{M}_{1}+$ cocopeat $(1: 1, \mathrm{v} / \mathrm{v})$ & 27.00 & 29.00 & 28.00 \\
\hline $\mathbf{M}_{\mathbf{6}} \mathbf{M}_{1}+$ vermicompost $(2: 1, \mathrm{v} / \mathrm{v})$ & 30.67 & 30.67 & 30.67 \\
\hline $\mathbf{M}_{7^{-}} \mathbf{M}_{1}+$ vermicompost + cocopeat $(2: 1: 1, \mathrm{v} / \mathrm{v})$ & 32.00 & 32.00 & 32.00 \\
\hline Mean & 26.38 & 28.72 & - \\
\hline
\end{tabular}

$\mathrm{CD}_{0.05}$ for:

Cultivars

0.67

Growing media

1.23

Growing media $\mathrm{x}$ Cultivars

1.74

Table.11 Effect of growing media on weight of stem (g) of LA hybrid cultivars 'Batistero' and 'Courier'

\begin{tabular}{|c|c|c|c|}
\hline \multirow[t]{2}{*}{ Growing media } & \multicolumn{2}{|c|}{ Cultivars } & \multirow[t]{2}{*}{ Mean } \\
\hline & Batistero & Courier & \\
\hline $\mathbf{M}_{1}$-sand+soil+FYM, $(1: 1: 1, \mathrm{v} / \mathrm{v})$ & 82.90 & 49.72 & 66.31 \\
\hline $\mathbf{M}_{2}$-sand+soil+FYM $(2: 1: 1, \mathrm{v} / \mathrm{v})$ & 78.15 & 44.64 & 61.40 \\
\hline $\mathbf{M}_{3}$-cocopeat+FYM $(1: 1, \mathrm{v} / \mathrm{v})$ & 78.27 & 45.33 & 61.80 \\
\hline $\mathbf{M}_{4}$-cocopeat+soil+FYM $(1: 1: 1, \mathrm{v} / \mathrm{v})$ & 74.87 & 45.33 & 60.10 \\
\hline $\mathbf{M}_{5}-\mathrm{M}_{1}+$ cocopeat $(1: 1, \mathrm{v} / \mathrm{v})$ & 83.65 & 56.81 & $\mathbf{7 0 . 2 3}$ \\
\hline $\mathbf{M}_{6-} \mathbf{M}_{1}+$ vermicompost $(2: 1, \mathrm{v} / \mathrm{v})$ & 88.85 & 57.92 & 73.40 \\
\hline $\mathbf{M}_{7}-\mathbf{M}_{1}+$ vermicompost + cocopeat $(2: 1: 1, \mathrm{v} / \mathrm{v})$ & 88.92 & 57.15 & 73.04 \\
\hline Mean & 82.23 & 50.98 & - \\
\hline \multicolumn{4}{|l|}{$\mathrm{CD}_{005}$ for: } \\
\hline Cultivars & 1.30 & & \\
\hline Growing media & 2.43 & & \\
\hline Growing media $\mathrm{x}$ Cultivars & NS & & \\
\hline
\end{tabular}


Table.12 Effect of growing media on vase life (days) of LA hybrid cultivars 'Batistero' and 'Courier'

\begin{tabular}{|c|c|c|c|}
\hline \multirow[t]{2}{*}{ Growing media } & \multicolumn{2}{|c|}{ Cultivars } & \multirow[t]{2}{*}{ Mean } \\
\hline & Batistero & Courier & \\
\hline $\mathbf{M}_{1}$-sand+soil+FYM, $(1: 1: 1, \mathrm{v} / \mathrm{v})$ & 11.00 & 10.00 & 10.50 \\
\hline $\mathbf{M}_{2}$-sand+soil+FYM $(2: 1: 1, \mathrm{v} / \mathrm{v})$ & 11.17 & 10.67 & 10.92 \\
\hline $\mathbf{M}_{3}$-cocopeat+FYM $(1: 1, \mathrm{v} / \mathrm{v})$ & 11.67 & 10.50 & 11.08 \\
\hline $\mathbf{M}_{4}$-cocopeat+soil+FYM $(1: 1: 1, \mathrm{v} / \mathrm{v})$ & 12.50 & 11.67 & $\mathbf{1 2 . 0 8}$ \\
\hline $\mathbf{M}_{5}-\mathrm{M}_{1}+$ cocopeat $(1: 1, \mathrm{v} / \mathrm{v})$ & 13.00 & 12.33 & 12.67 \\
\hline $\mathbf{M}_{6 .} \mathbf{M}_{1}+$ vermicompost $(2: 1, \mathrm{v} / \mathrm{v})$ & 14.83 & 13.67 & 14.25 \\
\hline $\mathbf{M}_{7-} \mathbf{M}_{1}+$ vermicompost + cocopeat $(2: 1: 1, \mathrm{v} / \mathrm{v})$ & 16.00 & 14.67 & $\mathbf{1 5 . 3 3}$ \\
\hline Mean & 12.88 & 11.93 & - \\
\hline \multicolumn{4}{|l|}{$\mathrm{CD}_{0.05}$ for: } \\
\hline Cultivars & 0.72 & & \\
\hline Growing media & 1.34 & & \\
\hline Growing media x Cultivars & NS & & \\
\hline
\end{tabular}

Among different growing media, maximum vase life (15.33 days) was observed in cut stems harvested from $\mathrm{M}_{7}\left(\mathrm{M}_{1}+\right.$ vermicompost + cocopeat; 2:1:1, v/v). Cut stems obtained from $\mathrm{M}_{\mathbf{6}}$ (14.25 days) $\left(\mathrm{M}_{1}+\right.$ vermicompost; $2: 1, \mathrm{v} / \mathrm{v})$ also gave similar results. On the other hand, minimum vase life (10.50 days) was recorded in $\mathrm{M}_{1}$ (sand + soil + FYM; $1: 1: 1 ; \mathrm{v} / \mathrm{v})$.

Although interaction between cultivar and growing media was non-significant (Annexure II), yet data shows that maximum vase life (16.00 days) was found when bulbs of LA hybrid 'Batistero' when grown in $\mathrm{M}_{7}$ $\left(\mathrm{M}_{1}+\right.$ vermicompost + cocopeat; 2:1:1;v/v). The same medium $\left(\mathrm{M}_{7}\right)$ was found to be the most effective for enhancing the vase life (14.67days) in 'Courier' also. In contrast, vase life was observed minimum in cv. 'Courier' (10.00 days) grown in $\mathrm{M}_{1}$ (sand + soil + FYM; 1:1:1; v/v).

The cut stems of cv. 'Batistero' showed better vase life than 'courier'. In both the cultivars cut stems raised on $\mathrm{M}_{7}\left(\mathrm{M}_{1}+\right.$ vermicompost + cocopeat; $2: 1: 1 ; \mathrm{v} / \mathrm{v})$ showed maximum vase life over other treatments. In lilium, vase life depends on number of buds per plant. Therefore, in the present study maximum vase life obtained in $\mathrm{M}_{7}$ can be directly co-related with corresponding higher number of buds (Table 8) in this treatment.

Further, maximization of various growth and flowering parameters as evident from the data in $\mathrm{M}_{7}$ might have resulted in production of quality cut stems with larger carbohydrate content supporting longer vase life.

\section{References}

Bostan, N., Sajid, M., Wahid, F., Rabi, F., Qureshi, S., Ahmad, W., Ahmad, S. and Tawab, S. 2014. Effects of growing media and irrigation interval on growth of Amaryllis (Amaryllis belladonna). Adv. Life Sci. Technol., 18: 2224-7181.

De Hertogh, A.A. 1989. Holland bulb forcers guide. Eds. 4. International Flower Bulb Centre, Hillegom, Holland.

Jong Jin Choi, Jong Suk Lee and Jong Myung Choi. 2002. Effect of physicochemical properties of growing media on growth, nutrient uptake and soil nutrient concentration in pot plant production of asiatic hybrid lily 'Orange Pixie'. $J$. Korean Society for Horticultural Sci., 43(6): 747-753.

Lyngdoh, A., Gupta, Y.C., Dhiman, S.R., 
Dilta, B.S. and Kashyap, B. 2015. Effect of substrates on the propagation of hybrid lilies through scaling. J. Hill Agri., 6(2): 158-162.

Moghadam, A.R.L., Ardebili, Z.O. and Saidi, F. 2012. Vermicompost induced changes in growth and development of Lilium Asiatic hybrid var. Navona. African J. Agri. Res., 7(17): 2609-2621.

Nikrazm, R., Ajirlou, S.A., Khaligy, A. and Tabatabaei, S.J. 2011. Effect of different media on vegetative growth of two Lilium cltivars in soilless culture. $J$. Sci. Technol.

Prisa, D., Burchi, G., Antonetti, M. and Teani, A. 2011. Use of organic or inorganic substrates for reducing the use of peat and improving the quality of bulbs infloresences in asiatic lily. Acta Horticulturae, 900: 143-148.

Rani, N., Kumar, R. and Dhatt, K.K. 2005. Effect of nitrogen levels and growing media on growth, flowering and bulb production of Lilium cultivars. $J$. Oranamental Horticulture, 8(1): 36-40.

Sahni, S., Sarma, B.K., Singh, D.P., Singh, H.B., Singh, K.P. 2008. Vermicompost enhances performance of plant growthpromoting rhizobacteria in Cicer arietinum rhizosphere against Sclerotium rolfsii and quality of strawberry (Fragaria $x$ ananassa Duch.). Crop Prot., 27: 369-376.

Seyedi, N., Torkashvand, A.M. and Allabyari, M.S. 2012. The impact of perlite and cocopeat as the growth media on Lilium. Asian J. Experimental Biol. Sci., 3(3): 502-505.

Singh, J. 2013. Standardization of growing substrates and NPK doses for growth and flowering of alstroemeria (Alstroemeria hybrida 1.) Ph.D. Thesis submitted to Dr. Y.S. Parmar University of Horticulture and Forestry, Nauni, Solan, Himachal Pradesh

Tomati, U., Grappelli, A., Galli, E. 1988. The hormone-like effect of earthworm casts on plant growth. Biol. Fertility of Soils, 5: 288-294.

Treder, J. 2005. Growth and quality of oriental lilies of different fertilization levels. Acta Hortculturae, 6673: 297302.

\section{How to cite this article:}

Smita Rajera, Puja Sharma and Bharti Kashyap Priyanka Sharma. 2017. Effect of Different Growing Media on Growth and Flower Production of LA Hybrid Lily. Int.J.Curr.Microbiol.App.Sci. 6(8): 2076-2089. doi: https://doi.org/10.20546/ijcmas.2017.608.247 